\title{
The psychosocial responses and coping strategies of diabetes mellitus type 2 patients of the Ambon culture
}

\section{Respon psikososial dan strategi koping pasien diabetes mellitus tipe 2 dengan budaya Ambon}

\author{
Rosiana Eva Ravanti ${ }^{1}$, Natalia Santika Wariunsora ${ }^{1}$, \& Simon Pieter Soegijono ${ }^{2}$ \\ ${ }^{1}$ Department of Nursing Science, Faculty of Medicine and Health Sciences, \\ Universitas Kristen Satya Wacana \\ ${ }^{2}$ Department Economic Development, Faculty of Economy, Universitas Kristen Indonesia Maluku \\ Address: ' Jalan Diponegoro 52-60 Salatiga, Central Java 50711 \\ ${ }^{2} J a l a n$ Ot Pattimaipauw, Nusaniwe, Ambon, Maluku 97115 \\ E-mail: rosiana.saragih@staff.uksw.edu
}

\begin{abstract}
A study conduct by the Global of Diabetic Federation showed that the prevalence of type 2 diabetes mellitus $(\mathrm{DM})$ is increasing at the international, national and regional levels. The prevalence of DM at Air Salobar Public Health Centre, Ambon, showed there to be an increase from 128 patients (2015) up to 221 patients (2016). There were changes observed in the physical and psychological responses of the patients with type 2 diabetes mellitus. Objective: To describe the psychosocial responses and coping strategies of the patients with type 2 diabetes mellitus in the context of Ambonese culture. Method: Qualitative and descriptive using the case study approach. There were four participants. The purpose sampling technique used the following criteria: patients with type 2 diabetes mellitus with complications (cataract, stroke, hypertension, heart attack or amputation), sick for $>$ two years, and the patients were Ambonese. The data collection was conducted through observation and in-depth interviews. Results: The participants' psychosocial responses included resilience, optimism and social support from their family and close relatives, low self-esteem, and anxiety. To adapt to their condition, the male participants tended to use problem-focused coping, while the female participants used emotion-focused coping. The factor that influenced the coping strategies was the diabetes severity, the participant's individual characteristics and the environment (culture and social support). They believe in traditional medicine such as the Africa leaf, noni fruit, kalabasa leaf and Alifuru leaf, and that the aforementioned traditional cures are able to reduce their blood glucose. Conclusion: although the participants have low self-esteem, and anxiety, they have resilience, optimism, and social support that allows them to endure DM.
\end{abstract}

Keywords: diabetes mellitus type 2; psychosocial response; coping strategies; Ambonese culture

\begin{abstract}
Abstrak
Studi Global International of Diabetic Federation menunjukkan prevalensi diabetes mellitus tipe (DM) 2 meningkat pada level internasional, nasional, regional. Prevalensi DM di Puskesmas Air Salobar Ambon meningkat dari 128 jiwa (2015) menjadi 221 (2016). Setelah menderita diabetes mellitus tipe 2 dengan komplikasi terjadi perubahan respon secara pkisis maupun fisik dan harus beradaptasi. Tujuan penelitian ini mendeskripsikan respon psikososial dan strategi koping pasien diabetes mellitus tipe 2 dalam konteks budaya Ambon. Metode yang digunakan dalam penelitian ini adalah kualitatif deskriptif dengan pendekatan case study pada empat partisipan. Kriteria teknik purposive sampling ialah pasien DM tipe 2 dengan komplikasi (katarak, stroke, hipertensi, jantung atau amputasi), sakit $>$ dua tahun, dan orang Ambon. Pengambilan data dengan observasi dan wawancara mendalam. Hasil penelitian ini adalah respon psikososial partisipan berupa resiliensi, optimisme sembuh, dukungan sosial, harga diri rendah, dan kecemasan. Strategi koping berupa problem focused coping dengan berfokus pada masalah sedangkan emotion focused coping berfokus pada emosi untuk penanganan stress. Partisipan pria cenderung berfokus pada masalah dan wanita berfokus pada emosional ketika berespon terhadap masalah. Pemilihan strategi koping dipengaruhi tingkat keparahan penyakit, karakteristik partisipan, dan lingkungan (budaya dan dukungan sosial). Partisipan percaya konsumsi obat tradisional daun afrika, buah mengkudu, daun kalibasa, dan daun alifuru dapat mengontrol kadar gula darah, walaupun partisipan mengalami harga diri rendah dan kecemasan, mereka memiliki resiliensi, sifat optimisme, dukungan sosial dalam menghadapi penyakit.
\end{abstract}

Kata kunci: diabetes mellitus tipe 2; respon psikososial; strategi koping; budaya Ambon 


\section{Introduction}

Insulin resistance resulting in metabolic disorders in the beta cells of the pancreas is called Diabetes Mellitus (DM) Type 2 (Fatimah 2015, State \& Biology 2013). Globally, the prevalence of this disease has increased from $6.2 \%$ to $11.9 \%$ in men and from $6.2 \%$ to $10.8 \%$ in women from 1989 to 2013 (Bovet \& Viswanathan 2014). Indonesia ranked sixth in the world with a total number of 10.3 million people with diabetes between the age of 20-79 in 2017 (International Diabetes Federation 2017). One of the provinces in Indonesia, Maluku, also has a 1\% DM incidence rate starting from the age of 15, although this situation is lower compared to the national prevalence of 1.5\% in 2013 (Health Research and Development Agency 2013). However, there was an increase in the incidence rate by $0.7 \%$, from 2007 to 2013 totalling $0.3 \%$ to $1 \%$ respectively (Health Research and Development Agency (Balitbangkes) Ministry of Health of the Republic Indonesia 2008). The Health Centre (Puskesmas) in Air Salobar Ambon located in Maluku capital city also showed an increase in the number of people with DM, from 128 people (2015) up to 221 people (2016). There is an increase in DM prevalence disease every year. It also causes complications, which affects the patients' body physically and psychologically. The form that the DM complications take could be hypoglycaemia, hyperglycaemia (Fatimah 2015), diabetic ketoacidosis, nephropathy, neuropathy and retinopathy, coronary heart disease, congestive heart failure, stroke, kidney failure, lower limbs amputations and blindness (International Diabetes Federation 2017). These complications will disrupt the physical activity of the patients, it could raise the depression (Bystritsky et al. 2014) and it could further make the patient dependent on others.

Type 2 DM cannot be cured (International Diabetes Federation 2017), especially in patients with complications. People with DM need to change their lifestyle, such as having a healthy diet, regular exercise, consuming their diabetes medications and routinely checking their blood sugar to control the glucose levels in their blood. Generally, individuals will respond to lifestyle changes with rejection, anxiety, anger, guilty feeling, and depression (Kumalasari \& Ahyani 2012). Psychologically, the resilience factor, the nature of their optimism, social support, low self-esteem, and depression is able to determine how the DM patients will respond to their condition after learning of their DM diagnosis (Donsu 2014). After responding to the news of their condition, the patient will experience and subconsciously enact different coping mechanisms, focusing on solving the problem or focusing on the emotional adjustment needed (Scheier et al. 1986, Wood \& Griffiths 2007). The patient's inability to adapt to the DM condition could result in disability (UK Diabetes 2014), depression (Bystritsky et al. 2014, Wood \& Griffiths 2007), increased medicine costs and premature death (Centers for Disease Control and Prevention 2017, UK Diabetes 2014, Oliva, Fernández-Bolaños, \& Hidalgo 2012)

Culture influenced the DM patients to having specific responses and coping mechanisms. Cultural values affect one's beliefs, values, and the individuals' habits when it comes to changing their mindset or behaviour in performing health practices (Jauhari 2016, Susanti \& Sulistyarini 2013). In the culture of Maluku's rural communities, they still believe in massage and spiritual beliefs, such as prayer to cure the disease. Patients who have diseases that are physically seen by others generally feel "Malu Hati (Embarrassed)", which is a lack of confidence. Psychological changes in patients with type 2 diabetes, particularly with complications, could worsen the patients' health. The purpose of this study was to describe the psychosocial responses and coping strategies of type 2 DM patients with complications in the cultural context in Ambon City, Maluku.

\section{Research Method}

The research method was descriptive and qualitative using a case study approach over two and a half months with the coverage area being the Health Centre of Air Salobar, Ambon City, in Maluku Province. The research instrument was in the form of an observation sheet and semi-structured, guided interview. The number of participants was four people, recruited using the purposive sampling technique. The participant criteria was that they were type 2 DM patients with complications (cataract, stroke, hypertension, or amputation) who had suffered from the disease for more than two years and that they were an Ambon native. Source triangulation was carried out via the family 
members, neighbours and medical personnel (doctors and nurses). The data analysis was conducted using the techniques of Miles and Huberman (Sugiyono 2016), consisting of the data collection, data reduction, presentation and conclusion.

\section{Results and Discussion}

The themes found were 1) psychosocial responses in the form of resilience, optimism, social support, low self-esteem, and anxiety; 2) coping strategies in the form of problem-focused coping and emotionfocused coping and 3) traditional medicine from the Ambonese cultural influence.

Table 1.

Profile and Medical Records of the Participants

\begin{tabular}{|c|c|c|c|c|}
\hline Indicator & P1 & P2 & P3* $^{*}$ & $\mathbf{P 4}^{* *}$ \\
\hline Age (year) & 67 & 52 & 73 & 55 \\
\hline Gender (M/F) & $M$ & $\mathrm{~F}$ & M & $\mathrm{F}$ \\
\hline Profession & $\begin{array}{l}\text { Retired civil } \\
\text { servant }\end{array}$ & Teacher & Farmer & Housewife \\
\hline $\begin{array}{l}\text { Illness } \\
\text { Duration }\end{array}$ & $\begin{array}{l}\text { Ten years } \\
(2007-2017)\end{array}$ & $\begin{array}{l}\text { Eight years } \\
(2009-2017)\end{array}$ & 36 yeas $(1981-2017)$ & $\begin{array}{l}\text { Four years } \\
(2013-2017)\end{array}$ \\
\hline Complication & $\begin{array}{l}\text { Hypertension and } \\
\text { cataract }\end{array}$ & $\begin{array}{l}\text { Right } \\
\text { hemiparesis; } \\
\text { stroke }\end{array}$ & $\begin{array}{l}\text { Heart disease, } \\
\text { cataract, amputation } \\
\text { of the lower left leg }\end{array}$ & Cataract \\
\hline
\end{tabular}

${ }^{*}$ Participant 3 died in May 2018, six months after the data collection. The participant (73 years old died in his sleep. The cause of death was old age and his high blood sugar level.

${ }^{* *}$ Participant 4 died in August 2018, eleven months after the data collection process. The participant (56 years old) died due to having a high blood sugar level and hypertension.

When suffering from DM, the four participants gave different responses to the initial stage and after having experienced type 2 diabetes mellitus. Their first response was anger, disappointment, and blaming others. However, after suffering for several years, P1, P3, P4 accepted their sickness, while P2 was still angry and blames others. Moreover, when faced with the DM diagnosis, not all individuals accept the disease. According to Kubler-Ross (2005), the loss stage shows after the phase of anger, going through denying and bargaining and leading to depression for several years until they are in the acceptance phase (Nash 2015).

\section{Resilience}

The four participants tried to adjust their physical condition through their daily activities. They wanted to go about their usual activities. However, they have physical limitations, such as cataract, their left foot having been amputated or having suffered from a stroke. These conditions are obstacles to doing everything normally. Previously, P2 was still actively working as a teacher, but she stopped working because of the diabetes along with the stroke complications. Participant 2 says:

\footnotetext{
"Before I had a stroke, I could still work. I do not want my children to do the work, so I am handling everything from the cooking through to the laundry. However, after I had a stroke, I could not do anything. I cannot cook, let alone do the laundry, and I now uses a stick to walk."
}

Only P1 still does activities outside of the home such as choir practice and cooking. Participant 3 maintained his diet well while the other three participants were still trying to obey the diabetes diet. Resilience itself is an adaptation process carried out by someone before and after encountering a problem in life (Mahmood \& Ghaffar 2014, Mawarpury \& Mirza 2017, Musabiq \& Meinarno 2017). The disease's severity, such as complications and other diseases, can cause people with diabetes to stop working (Von Korff et al. 2005). The participants had to adjust their lifestyle (Tristiana et al. 2016) such as keeping to a healthy diet, exercise and consuming the drugs needed to control their blood sugar level to within the normal limits (International Diabetes Federation 2017, Pillay et al. 
2015). Adaptability influences the participants' ability to manage their diabetes and control their blood sugar level (Yi-Frazier et al. 2012). Groups with an adequate through to a low level of resilience have high HbA1c levels in their blood sugar (Massey et al. 2016, Yi, Vitaliano, \& Smith 2008).

\section{Optimism}

The participants expect to recover from DM. They follow the recommendations or prohibitions that they are informed of by the nurses and doctors. Moreover, the participants have confidence when dealing with their illness, which is caused by going to the doctor or health centre. Participant 2 said that "My children are the biggest motivation for my mom is my children. They sometimes get tired because of taking care of me, so they want me to get well very soon". Participant 1 said: "In the beginning, it felt difficulty, but I had to take it if I wanted to be healthy". The nature of optimism is self-confidence and hope when dealing with problems (Carver et al. 2010, Musabiq \& Meinarno 2017). The four participants tried to make changes in their lifestyle to maintain their blood sugar level — this included avoiding oily foods and taking their medicine regularly (International Diabetes Federation 2017, Pillay et al. 2015). The behaviour of using the healthcare services available is a part of diabetes management (Sarafino \& Smith 2011). Theoretically, optimism and health are interrelated. Optimism is an indicator related to achieving health (Boehm et al. 2015), including for diabetics patients (Puig-Perez et al. 2017). Someone who has self-confidence, or the confidence that they will recover, will have a healthy body.

All of the participants were Protestant and they were confident that they would recover from their disease. Religious factors influenced their confidence in the possibility of recovery (Husna \& Linda 2014, Koenig 2004, Oxhandler et al. 2017). Based on Ambon City Statistics Centre in 2016, the most popular religion in Ambon City was Protestant (47.6\%) (Ambon City Central Statistics Agency 2017). The values of the Protestant faith teach believers to trust in God's help when recovering from an illness (de Vyver 2009).

\section{Social Support}

It is necessary that the DM patients receive support from their husband/wife, children, and grandchildren such as serving food and drink, providing medicine, and giving them the motivation to recover. Close relatives can also provide advice and motivation. This support is helpful for the participants, to allow them to continue with their lives. Participant 1 said, that "family support is important". Participant 2 said that their "children's assistance and care has made them strong". Participants 3 and 4 had children who kindly assisted their parents when it was time for them to have a medical check-up. Participant 3 said that "the children usually inject my drugs for me, usually in the hands, if not in the stomach. My children also check my blood sugar frequently". Participant 4 said "My daughter usually visits me to check my blood pressure and sugar level. Whereas the youngest helps if I want to take medicine. She often puts it in the stove to cook." Social support is focused on giving attention, affection, and acceptance to improve the individual's level of comfort (Jauhari 2016, Kumalasari \& Ahyani 2012). The participants receive support from the people closest to them, such as their family, co-workers, friends and even the medical team (doctors and nurses) in the form of attention, respect, and love. The feeling of acceptance and attention from their family can help them to live their lives (Mark \& Richard 2007). Furthermore, support and communication from their family members and relatives, such as reminding them how to manage their diabetes, can help the participants to change their behaviour (Hood et al. 2015, Yi-Frazier et al. 2012). The social and cultural context is also capable of influencing the adaptation process (Moonaghi et al. 2014). The culture of "pela gandong" is still intertwined in Ambon City society and it is one of the supporting factors of the people closest to the participants (Desi et al. 2017).

\section{Low Self-esteem}

Ambonese people usually feel "embarrassed" when they experience a disease that involves physical limitations. Low self-esteem is a guilty feeling, or it can be where they are uncomfortable with themselves. The participants' present condition makes them embarrassed to meet other people 
because of the illness. A mother cannot perform their duties, and they are unable to take part in social activities in the environment until asking for help from others.

Participant 1 said that "The little children are afraid to be close. Usually, I say that cataracts is because of hot water". Participant 4 said: "If I try to ask someone for help, I am embarrassed".

Low self-esteem is the feeling of worthlessness, insignificance and prolonged inferiority due to a negative self-evaluation (Desi 2013, Mahdi et al. 2013). The participants in this study had low selfesteem, experiencing feelings such as shame due to their physical condition, particularly after they developed cataract and complications from a stroke. Changes in family status and the inability to work led to low self-esteem in the participants (Von Korff et al. 2005).

\section{Anxiety}

The conditions and demands experienced by the participants make them uncomfortable or they feel as though they are under pressure. All of the participants experienced complications that caused them to feel depressed. For instance, after cataract surgery, hypertension, or having their left foot or left leg amputated. In addition to this, they also have to adhere to a diabetes diet. Participant 1 said: "Because I have cataracts, I have to experience eye surgery. I am the most depressed at that moment. I talk to my wife about what is the best solution".

Two female participants (P2 and P4) had other anxiety triggers, namely related to the condition of their household. When we conducted the interview, they cried when we asked about their child's health condition. Participant 2 said: "My husband has had so many affairs with many women. He did not think about the children. At the time, I was not too bothered because I could pay for the children without my husband's help. However, now I am no longer capable of funding my children's needs, even though I still have a salary. It is not the same as before. Psychologically, almost every day, I feel the burden, and it continues to be there. It is a most burdened time".

The psychology of women is, broadly speaking, emotional, sensitive, expressive, and they often cry when experiencing a problem (Nurhayati 2016). One participant felt burdened because her husband had had an affair and the other was strained because his daughter had died and left her child behind, in addition to the participants' 4 grandsons. The interpretation of anxiety in this study is neurotic helplessness, insecurity, confusion, uncertainty (Taluta \& Hamel 2014), immaturity, a lack of ability (Annisa 2016, Sabai, Aluih, \& Sicincin 2017) when facing realistic demands (environment), and the difficulties and pressures of daily life. The anxiety felt by the participants was caused by the limitations in their routine functioning due to DM complications (Massey et al. 2016, Sarafino \& Smith 2011). Anxiety and depression can worsen diabetes, such as promoting an abnormal blood glucose level and functional disorders (Sarafino \& Smith 2011), non-compliance in taking medication, complications (de Groot et al. 2016) and death (Massey et al. 2016).

\section{Coping Strategy}

This research showed that there are factors that support the participants in the selection of the most suitable coping strategy for them. The factors consist of the severity of the disease, their individual characteristics, and the environment. The disease severity includes the duration of the illness being more than two years, complications, limitations when doing their daily activities and behavioural changes in the form of a diabetic diet. The individual characteristics cover gender (Lestarianita \& Fakhrurrozi 2007) and the post-conflict nature of the Ambonese people (Bakri 2015). The environment includes the consumption of traditional medicine, the beliefs based on religion that they are able to recover, and the culture of "Pela Gandong" (Bakri 2015, Desi, Tomasoa \& Soegijono 2017, Malisngorar \& Sugiswati 2017). Patients with chronic diseases, such as DM, generally resort to emotion-focused coping after being diagnosed with the illness. The patients also encounter feelings of denial, along with the DM signs and symptoms in addition to affirming that the disease has been diagnosed. The patient will then be enter in the stage of adjustment. When the sufferers feel that they are unable to solve their problems, they will respond emotionally (Sarafino \& Smith 2011). 
The feeling of rejection and denial leads to inadaptability. Conversely, the patients used problemfocused coping when they made emotional adjustments to the diabetes disease. The character of the Ambonese is known to be stubborn, and this also influences them when choosing a coping strategy.

All of the participants used both forms of coping strategy when facing stressors. However, they focused more on one coping form than the other. The two male participants more often used a coping strategy that focused on the problems while the two female participants focused on the problem's emotional settings. According to Hamilton and Fagot in Lestarianita \& Fakhrurrozi (2007), male participants usually use logic rather than their feelings, while female participants manage their emotions (Nurhayati 2016) when solving a problem.

Solving problems can be done using both forms of coping strategy, focusing on solving the problem or managing the emotions involved (Sarafino \& Smith 2011, Tri 2012). All of the participants chose either problem-focused coping or emotion-focused coping. Crisis theory underlies the selection of the coping strategies by the patients with chronic disease, involving disease-related factors, individual characteristics, and environmental factors (physical and social) (Sarafino \& Smith 2011, Safaria \& Saputra 2012).

\section{Problem-focused coping}

The patients suffer from diabetes mellitus with complications, which can cause other health problems such as amputations, hypertension, stroke and cataract. When they get sick, the participants check their condition with the doctor at the Health Centre and at the Hospital. Participant 1 said:

"I often go to the health centre. If I go to the doctor, I am certain that the medicine that will be given to me is hard medicine, so we never want to go to the doctor". Participant 2 said "I told the children to take me to the hospital. If I feel pain, I immediately tell the children to take me to the doctor". Participant 3 said, "I was treated at the Bhakti Rahayu Hospital at the Health Centre".

Strategies that are problem-focused are often used to immediately to solve the problems themselves (Ari 2015, Nindya 2013, Pramadi \& Lasmono 2003). The actions taken by the participants are adaptive mechanisms; taking decisive actions to reduce stress (Albai et al. 2017, Suri \& Vaidya 2015), such as medical treatment.

\section{Emotion-focused coping}

Female participants tend to use feelings or emotions when dealing with a problem. Participant 2 says:

"I am disappointed and angry; why did it have to be me? I have children who are still enrolling school, why do I have to be sick with diabetes? Why isn't my husband sick? My husband ignores our children, why does it have to be me? I cannot do anything." Participant 4 said, "If I am emotional, I usually keep it quiet. I do get angry if they (kids) don't wash the dishes, but after, I just wash the dishes myself".

Men are more surrendered, as Participant 1 said:

"At first, I was shocked and scared for a long time, and then I was not affected anymore". Participant 3 said "I am angry when my legs must be cut off. Is there no medicine? Poor me. I work in the garden, and my wife sells at the market. How can we could afford the living costs when one of my legs is being cut off".

Effective focused coping can be an effective way of solving a problem (Diyan 2016, Donsu 2014). The female participant's blame others for their bodily condition, regret what had happened, or emotionally ran away by pretending not to know their reality (Nindya 2013, Yunita \& Lestari 2017). When interviewed, the participants cried when we asked about any family health conditions and diabetes in particular. They are still in the denial stage, according to Kubler-Ross (2005) (Yunita 
\& Lestari 2017). If the participants are unable to manage their feelings or emotions for a long period of time, then this will lead to inadaptability mechanisms. Inadaptability mechanisms include rejection, self-blame, and self-diversion (Kasi et al. 2012). The use of these mechanisms is capable of increasing depression and reducing the adherence to diabetes management (Albai et al. 2017), which is detrimental to the participants' health.

\section{Culture}

The participants believe that the consumption of traditional medicines such as leaves can reduce their blood sugar levels, which is a hereditary belief. Information about the leaf types and leaf processing were obtained from the participant's relatives, who stated that they had had the knowledge for generations or that they had gained it from other people's experiences. Furthermore, the traditions and habits of society could influence the views on medication within the community. The consumption of traditional medicine comes in the form of African leaves, kalabasa leaves, alifuru leaves and noni fruit. These leaves are typical plants in Ambon. The following are the participant's relevant statements:

"There is a story about African leaves. First, it is like drinking an old tea (a type of gopard) and drinking it without sugar will give it an adequate level of protein. There are kersen leaves and cinnamon in it. I once got cinnamon root and soaked it in boiling water, and drank it when it was cold" (P1).

“.... the organisation says that the village medicine involves kalabasa leaves, which also have large fruits. In the village, people like to make sageru. There is also pare, which I drinks" (P2).

"There called noni fruit. People promote it, so I tried it. I drank it to lower my blood sugar" (P4).

The following are the African leaf species (Vernonia amygdalina) (Osinubi 2008), Alifuru leaves (Graptophyllum pictum) (Rahmi et al. 2014, Wati, Rahmawati, \& Masawoy 2015), kersen leaves (Muntingia calabura L.), cinnamon root (Cinnamomum chinese BL.), pheasant leaves (Anredera cordifolia), kalabasa leaves (Aegle Marmelos L. Corr. Serr.), papari fruit (Momordica charantia) (Adnyana et al. 2016), Dutch jackfruit leaves (Annona uricata L.) (Dwi et al. 2015), biyana leaves (Coleus bumei), lemon basil leaves (Ocimum basilicum), noni fruit (Morinda citrifolia) (Wowor 2016), the bitter medicine made from the manggustan skin (Garcinia mangostana), and male berries (Inocarpus fagiferus) used to reduce blood glucose levels.

Generally, processing the leaves involves boiling them or soaking them in hot water. The leaves will then be drank, or directly eaten/squeezed and then swallowed. Cooking the traditional medicine is done using a ground pot and a fire stove (or wood stove). The methods used for processing the traditional medicines include boiling, pounding, grinding (using tools) and drinking (Yulia 2016). Papari and bengkudu are grated and soaked in hot water, left until warm and then drank. The other leaves are boiled (with an odd number of leaves) and then drank. The following are the participants' statements on traditional medicine:

\footnotetext{
"It tastes usual. I boil five to seven sheets of leaves" (P1).

"Cooked only. The cooked leaves must be of an odd number, and then boiled with one scoop of water or three cups until you get one glass to drink" (P2).

"I don't know, but I boiled first and then drank it" (P3).

"Yes, bengkudu fruit; I grated and squeezed it with a small cloth and drank one spoonful. I drank it four times and my sugar blood level decreased by more than 300" (P4: pp.158-160).
}

Existing habits will affect each member of a community differently (Nurhalimah 2015). For generations, the use of traditional medicine in Ambon City is a common method of treating disease 
(Mulyani, Widyastuti, \& Ekowati 2016). All of the participants knew about the traditional medicines available from the closest people to them, namely their friends, neighbours, and families (Sembiring \& Sismudjito 2015). The reasons for choosing traditional medicine are based on experience, in addition to the economic and cultural factors involved (Fanani \& Dewi 2014, Kartika \& Sewu 2016, Leonita \& Muliani 2015). The financial status of all middle to lower income participants, such as participants 1 and 2, means that they rely on their pension and basic salary as a teacher respectively. For participants 3 and 4, their income came from selling in the market and the funding that they received from the government for the care of their children each month.

\section{Conclusion}

The psychosocial responses of the participants with type 2 diabetes mellitus were resilience, an optimistic nature and receiving social support from their family and relatives. However, the participants had low self-esteem and anxiety about the disease. The coping strategy used most often by men was problem-focused coping, focusing on the problems, while the women used emotionfocused coping, focusing on their emotions. Ambon culture, in the form of traditional medicine using herbal leaves from generation to generation, is a community treatment used to reduce blood sugar levels.

\section{References}

Adnyana IDPA, Meles DK, Wurlina SZ, \& Suwasanti N (2016) Efek anti diabetes buah pare (Momordica charantia Linn.) terhadap kadar glukosa darah, sel penyusun Pulau Langerhans dan Sel Leydig pada tikus putih hiperglikemia. Acta Veterinaria Indonesiana 4 (2):43-50.

Albai A, Sima A, Papava I, Roman D, Andor B, \& Gafencu M (2017) Association between coping mechanisms and adherence to diabetes-related self-care activities: A cross-sectional study. Patient Preference and Adherence 11:1235-1241. https://doi.org/10.2147/PPA.S140146.

Annisa DF (2016) Konsep kecemasan (Anxiety) pada lanjut usia (Lansia). Konselor 5 (2):93-99. https://doi.org/10.24036/02016526480-0-00.

Ari SA (2015) Stres dan Strategi Koping Pada Narapida Wanita di Lembaga Permasyarakatan Kelas II A Wanita Semarang.

Bakri H (2015) Resolusi konflik melalui pendekatan kearifan lokal Pela Gandong di Kota Ambon. The POLITICS: Jurnal Magister Ilmu Politik Universitas Hasanuddin 1 (1):51-60.

Boehm JK, Trudel-Fitzgerald C, Kivimaki M, \& Kubzansky LD (2015) The prospective association between positive psychological well-being and diabetes. Health Psychology 34 (10):10131021. https://doi.org/10.1037/hea0000200.

Bovet P \& Viswanathan B (2014) National survey of noncommunicable diseases in Seychelles 2013-2014 (Seychelles Heart Study IV): Methods and main findings National Survey of Noncommunicable Diseases in Seychelles 2013-2014, (June 2015).

Bystritsky A, Danial J, \& Kronemyer D (2014) Interactions between diabetes and anxiety and depression: Implications for treatment. Endocrinology and Metabolism Clinics of North America 43 (1):269-283. https://doi.org/10.1016/j.ecl.2013.10.001.

Carver CS, Scheier MF, \& Segerstrom SC (2010) Optimism. Clinical Psychology Review 30 (7):879889. https://doi.org/10.1016/j.cpr.2010.01.006

Centers for Disease Control and Prevention (2017) National Diabetes Statistics Report, 2017 Estimates of Diabetes and Its Burden in the Epidemiologic estimation methods. US Department of Health and Human Services. https://doi.org/10.1177/1527154408322560.

de Groot M, Golden SH, \& Wagner J (2016) Psychological conditions in adults with diabetes. American Psychologist 71 (7):552-562. https://doi.org/10.1037/a0040408.

de Vyver HMV (2009) Andrew Murray's theology of divine healing. VERBUM ET ECCLESIA JRG $30(1): 302-319$. 
Desi, Tomasoa SJ, \& Soegijono SP (2017) Well-being: Studi Sosiodemografi di Ambon. Jurnal Keperawatan Muhhamadiyah 2 (2).

Desi P, Keliat BA, \& Wardani IY (2013) Pemberdayaan Keluarga dan Kader Kesehatan Jiwa dalam Penanganan Pasien Harga Diri Rendah Kronik dengan Pendekatan Model Precede L. Green di RW 06, 07 dan 10 Tanah Baru Bogor Utara. Jurnal Keperawatan Jiwa 1 (2):170-177.

Diyan KD (2016) Stress dan strategi koping pada anak pidana. Psikoborneo 4 (3):483-493.

Donsu JDT (2014) Peran faktor-faktor psikologis terhadap depresi pada pasien diabetes mellitus tipe 2. Jurnal Psikologi 41 (1):241-249.

Dwi NGAM, Suastuti A, Sri IGAK, Dewi P, Ni D, \& Ariati K (2015) Pemberian ekstrak daun sirsak (annona muricuta) untuk memperbaiki kerusakan sel beta pankreas melalui penurunan kadar glukosa darah, advanced glycation and product dan 8-hidroksi-2-dioksiguanosin pada tikus wistar hiperglikemia. Jurnal Kimia 9 (2):289-295. https://doi.org/ISSN 1907 - 9850.

Fanani S \& Dewi TK (2014) Health belief model pada pasien pengobatan alternatif supranatural dengan bantuan dukun. Jurnal Psikologi Klinis Dan Kesehatan Mental 03 (4):54-59.

Fatimah RN (2015) Diabetes melitus tipe 2. J Mayority 4 (5):93-101.

Hood KK, Hilliard M, Piatt G, \& Ievers-Landis CE (2015) Diabetes management effective strategies for encouraging behavior change in people with diabetes. Diabetes Manag 5 (6):499-510. https://doi.org/10.2217/dmt.15.43.

Husna \& Linda (2014) Hubungan spiritualitas dengan harga diri pasien ulkus diabetik di poliklinik endokrin Rumah Sakit Umum Daerah dr. Zainoel Abidin Banda Aceh tahun 2014. Idea Nursing Journal (2087-2879):61-68.

International Diabetes Federation. (2017). IDF DIABETES ATLAS Eighth edition 2017. http:// www.diabetesatlas.org/

Jauhari (2016) Dukungan sosial dan kecemasan pada pasien diabetes melitus. The Indonesian Journal of Health Science 7 (1):64-76.

Kartika D, Sewu PLS, \& W. Rullyanto (2016) Pelayanan kesehatan tradisional dan perlindungan hukum bagi pasien. SOEPRA Jurnal Hukunm Kesehatan 2 (1).

Kasi PM, Naqvi HA, Afghan AK, Khawar T, Khan FH, Khan UZ, \& Khan HM (2012) Coping Styles in Patients with Anxiety and Depression. ISRN Psychiatry:1-7. https://doi. org/10.5402/2012/128672.

Koenig HG (2004) Religion, spirituality, and medicine: Research findings and implications for clinical practice. South Med J 97 (12):1194-1200. https://doi.org/10.1097/01. SMJ.0000146489.21837.CE.

Kumalasari F \& Ahyani LN (2012) Hubungan antara dukungan sosial dengan penyesuaian diri remaja di panti asuhan. Jurnal Psikologi Pitutur 1 (1):21-31.

Leonita E \& Muliani A (2015) Penggunaan obat tradisional oleh penderita diabetes mellitus dan faktor-faktor yang berhubungan di wilayah kerja Puskesmas Rejosari Pekanbaru Tahun 2015. Jurnal Kesehatan Komunitas 3 (1).

Lestarianita P \& Fakhrurrozi M (2007) Pengatasan stres pada perawat pria dan wanita. Jurnal Psikologi 1 (100):47-51.

Mahdi HM, Tahun B, Suerni T, Anna B, Helena N, Jiwa K, \& Semarang G (2013) Klien harga diri rendah di ruang yudistira rumah sakit dr .H. Marzoeki Mahdi Bogor tahun 2013. Jurnal Keperawatan Jiwa 1 (2):161-169.

Mahmood K \& Ghaffar A (2014) The relationship between resilience, psychological distress and subjective well-being among dengue fever survivors. Global Journal of Human-Social Science Research 14 (10). ISSN 2249-460X. https://socialscienceresearch.org/index.php/ GJHSS/article/view/1223.

Malisngorar \& Sugiswati (2017) Pela gandong sebagai sarana penyelesaian konflik. Perspektif 22 (1):183-189. 
Mark P \& Richard RR (2007) Behavioral and psychosocial interventions. Diabetes care 30. https:// doi.org/10.2337/dc07-1222.Abbreviations.

Massey CN, Feig EH, Duque-Serrano L, \& Huffman JC (2016) Psychological Well-being and type 2 diabetes. Curr Res Diabetes Obes Journal 4 (4):87-92. https://doi.org/10.1016/j. coviro.2015.09.001.Human.

Mawarpury M \& Mirza (2017) Resiliensi dalam keluarga: Perspektif psikologi. Jurnal Psikoislamedia $2(1): 96-106$.

Mulyani HM, Widyastuti SH, \& Ekowati V (2016) Tumbuhan herbal sebagai jamu pengobatan tradisional terhadap penyakit dalam serat Primbon Jampi Jawi jilid I. Jurnal Penelitian Humaniora 21 (2):73-91.

Moonaghi HK, Areshtanab HN, \& Jouybari L (2014) The efficacy of optimism: Benefit finding in the treatment of diabetes in Iranian patients. ISRN Nursing: 1-6. https://doi. org/10.1155/2014/371296.

Musabiq SA \& Meinarno EA (2017) Optimisme sebagai prediktor psikologis pada mahasiswa kebidanan. Jurnal Kedokteran dan Kesehatan 13 (2):134-143.

Nash J (2015) Dealing with diagnosis of diabetes. Practical Diabetes 32 (1):19-23. https://doi. org/10.1002/pdi.1915.

Nindya W (2013) Strategi Koping Menghadapi Stres Dalam Penyusunan Tugas Akhir Skripsi, Program S1 Fakultas Ilmu Pendidikan.

Nurhalimah (2015) Upaya dinas kebudayaan pariwisata pemuda dan olahraga dalam menyelenggarakan kegiatan bidang kebudayaan di Kabupaten Nunukan. E-Journal Ilmu Pemerintahan 3 (1):239-252.

Nurhayati E (2016) Memahami psikologis perempuan (Integrasi \& intercomplementer perspektif psikologi dan Islam). Batusangkar International Conference 1 (15-16 October):245-258.

Oliva J, Fernández-Bolaños A, \& Hidalgo Á (2012) Health- related quality of life in diabetic people with different vascular risk. BMC Public Health 12 (1):812. https://doi.org/10.1186/14712458-12-812.

Osinubi AAA (2008) Effects of vernonia amygdalina and chlorpropamide on blood sugar. Medical Journal of Islamic World Academy of Sciences 16 (3):115-119.

Oxhandler H, Polson E, Moffatt K, \& Achenbaum W (2017) The religious and spiritual beliefs and practices among practitioners across five helping professions. Religions 8 (11):237. https:// doi.org/10.3390/rel8110237.

Pillay J, Chordiya P, Dhaka IS, Vandermeer B, Hartlin L, Armstrong M, \& Dryden D (2015) Behavioral programs for diabetes mellitus evidence report/technology assessment No. 221. (Prepared by the University of Alberta Evidence-based Practice Center under Contract No. 290-2012-00013-I.). In AHRQ Publication No. 15-E003-EF (pp. 1-310). https://doi.org/ https:// doi.org/10.23970/AHRQEPCERTA221.

Pramadi A \& Lasmono HK (2003) Koping stress pada etnis Bali, Jawa dan Sunda. Indonesian Psychological Journal 18 (N):326-340.

Puig-Perez S, Hackett RA, Salvador A, \& Steptoe A (2017) Optimism moderates psychophysiological responses to stress in older people with Type 2 diabetes. Psychophysiology 54 (4):536-543. https://doi.org/10.1111/psyp.12806.

Rahmi H, Artika IM, Azwar NR, Sasongko D, \& Seno H (2014) The activity of wungu leaf (Graptophyllum pictum (L) Griff) extract in reducing blood glucose level of hyperglycemic mice. Current Biochemistry 1 (2335-7877):83-88.

Sabai W, Aluih NAN, \& Sicincin P (2017) Kondisi kecemasan lansia di Panti Sosial Tresna. Jurnal Fokus Konseling 3 (1):57-66.

Sarafino EP \& Smith TW (2011) Health psychology biopsychosocial interactions. Journal of Psychosomatic Research 35 (4-5):625. https://doi.org/10.1016/0022-3999(91)90058-V. 
Scheier MF, Weintraub JK, \& Carver CS (1986) Coping with stress: Divergent strategies of optimists and pessimists. Journal of Personality and Social Psychology 51 (6):125-1264. https://doi. org/10.1037/0022-3514.51.6.1257.

Sembiring S \& Sismudjito (2015) Pengetahuan dan pemanfaatan metode pengobatan pada masyarakat Desa Suka Nalu Kecamatan Barus Jahe. Perspektif Sosiologi 3 (1):104-117.

State A \& Biology E (2013) The pathogenesis and pathophysiology of type 1 and type 2 diabetes mellitus 4 (4):46-57. https://doi.org/10.5897/JPAP2013.0001.

Suri D \& Vaidya VA (2015) The adaptive and maladaptive continuum of stress responses - A hippocampal perspective. Reviews in the Neurosciences 26 (4):415-442. https://doi. org/10.1515/revneuro-2014-0083.

Susanti ML \& Sulistyarini T (2013) Dukungan keluarga meningkatkan kepatuhan pasien diabetes melitus di ruang rawat inap RS Baptis Kediri. Jurnal STIKES 6 (1):1-10.

Taluta YP \& Hamel RS (2014) Hubungan tingkat kecemasan dengan mekanisme koping pada penderita diabetes mellitus tipe ii di poliklinik penyakit dalam Rumah Sakit Umum Daerah Tobelo Kabupaten Halmahera Utara. E-Journal Keperawatan 2 (1).

Tri WJ (2012) Stres dan strategi coping pada siswa yang tidak lulus Ujian Nasional. Psikopedagogia 1(2) ISSN: 2301-6167.

Tristiana RD, Kusnanto, Widyawati IY, Yusuf A, \& Fitryasari R (2016) Psychological well being in type 2 diabetes mellitus patients in Mulyorejo Public Health Center Surabaya. Jurnal NERS 11 (2):147. https://doi.org/10.20473/jn.V11I22016.147-156.

UK Diabetes (2014) Diabetes-key-stats-guidelines-April2014-1. Diabetes UK (3):1-21. http:// scholar.google.com/scholar?hl=en\&btnG=Search\&q=intitle:DIABETES+:+FACTS+AND +STATS\#5.

Von Korff M, Katon W, Lin EHB, Simon G, Ciechanowski P, Ludman E, \& Young B (2005) Work disability among individuals with diabetes. Diabetes Care 28 (6):1326-1332. https://doi. org/10.2337/diacare.28.6.1326.

Wati A, Rahmawati, \& Masawoy DS (2015)Activity of ethanol extract of purpleleaves (Graptophyllum pictum (Linn.) Griff.) Onalloxan-Induced DiabetesMice. International Journal of PharmTech Research 7 (3):497-501.

Wood RTA \& Griffiths MD (2007) A qualitative investigation of problem gambling as an escapebased coping strategy. Psychology and Psychotherapy: Theory, Research and Practice 80 (1):107-125. https://doi.org/10.1348/147608306X107881.

Wowor MP (2016) Uji beberapa dosis ekstrak buah mengkudu (Morinda citrifolia 1.) terhadap kadar glukosa darah pada tikus wistar (Rattus norvegicus) yang diinduksi aloksan. Jurnal E-Biomedik (EBm) 4 (2).

Yi-Frazier JP, Hilliard M, Cochrane K, \& Hood KK (2012) The Impact of positive psychology on diabetes outcomes: A review. Psychology 3 (12A):1116-1124. https://doi.org/10.4236/ psych.2012.312A165.

Yi JP, Vitaliano PP, \& Smith RE (2008) The role of resilience on psychological adjustment and physical health in patients with diabetes. Br J Health Psychol 13 (Pt 2):311-325. https://doi. org/10.1348/135910707X186994.

Yulia NI (2016) Studi etnofarmasi penggunaan tumbuhan obat oleh Suku Tengger di Kabupaten Lumajang dan Malang, Jawa Timur. Pharmacy 13 (01):10-20.

Yunita A \& Lestari MD (2017) Proses grieving dan penerimaan diri ibu rumah tangga berstatus HIV Positif yang tertular melalui suaminya. Jurnal Psikologi Udayana 4 (2):223-238. 